\title{
Ants Promote Germination of the Tree Guarea guidonia by Cleaning its Seeds
}

\author{
Bianca Ferreira Silva ${ }^{1}$ (D), Igor Henrique Freitas Azevedo ${ }^{2}$ (D), \\ Antonio Mayhé-Nunes ${ }^{3}$ (D), Tiago Breier ${ }^{4}$ (D), Andre Felippe Nunes de Freitas ${ }^{1}$ \\ ${ }^{1}$ Departamento de Ciências Ambientais, Instituto de Florestas, Universidade Federal Rural do Rio de Janeiro - UFRRJ, \\ Seropédica/RJ, Brasil \\ ${ }^{2}$ Departanento de Botânica, Instituto de Biociências, Universidade Estadual Paulista Julio de Mesquita Filho - UNESP, \\ Rio Claro/SP, Brasil \\ ${ }^{3}$ Departamento de Biologia Animal, Instituto de Biologia, Universidade Federal Rural do Rio de Janeiro - UFRRJ, \\ Seropédica/RJ, Brasil \\ ${ }^{4}$ Departamento de Silvicultura, Instituto de Florestas, Universidade Federal Rural do Rio de Janeiro - UFRRJ, \\ Seropédica/RJ, Brasil
}

\begin{abstract}
Ants interact with seeds, and frequently remove their appendages. This work aimed to evaluate the effect of ants on the germination of Guarea guidonia (Meliaceae) seeds through removing the fleshy tissue of their integument (sarcotesta). The seeds were subjected to the following treatments: control (no sarcotesta removal), manual removal, and removal by ants. The results show that germination percentage and time varied among treatments, with removal by ants showing the highest percentage within the shortest possible time. The positive effect of sarcotesta removal by ants points to a possible action of anti-fungal substances. As germination is an essential step for recruitment, ant activity may be important to the regeneration of a deforested area. Further studies should consider germination experiments under natural conditions in order to increase the understanding on plant development.
\end{abstract}

Keywords: ant-plant interaction, recruitment, seed germination, Solenopsis, Atlantic Forest.

\section{INTRODUCTION}

In tropical environments, several plants are dispersed by animals (Schupp et al., 2010). Over 70\% of the species in tropical forests are zoochoric, and this number may reach up to $90 \%$ in some places (Morellato \& Leitão-Filho, 1992). However, the lack of dispersers in deforested regions hinder dispersal (Cole et al., 2010; Brudvig et al., 2011). Ants are among the common tropical dispersers, especially in ecologically degraded environments (Henao-Gallego et al., 2012). They interact with a broad variety of fruits and seeds while foraging for pulp or aril and as a result promote seed dispersal (Christianini \& Oliveira, 2010; Christianini et al.,
2012; Escobar-Ramírez et al., 2012; Bieber et al., 2013; Lima et al., 2013; Santana et al., 2013; Gallegos et al., 2014).

The interaction of ants with fruits and seeds can result in their removal from the place where they were primarily deposited (Santana et al., 2013; Gallegos et al., 2014). This removal can benefit seeds and promote their germination and development. Furthermore, ants can also clean fruits and seeds (Christianini et al., 2007; Christianini \& Oliveira, 2010; Gallegos et al., 2014). Cleaning occurs when ants find fruits and seeds, usually close to the mother plant. On the one hand, cleaning by 
ants may be negative for recruitment as diaspores may lose parts that could attract other potential dispersers (Christianini \& Oliveira, 2010). In addition to that, the seed remains in an area of high propagule density and mortality (Janzen, 1970; Connell, 1971; Christianini \& Oliveira, 2010). On the other hand, cleaning may be positive, as it frequently results in the protection against pathogens which favors seed germination and seedling recruitment (Oliveira et al., 1995; Ohkawara \& Akino, 2005; Christianini et al., 2007; Santana et al., 2013; Camargo et al., 2016).

Ants remove the aril, pulp or other existing appendages by cleaning the seeds or fruits. This cleaning reduces infection by pathogens due to antifungal chemicals applied by the ants (Ohkawara \& Akino, 2005). Secretions produced by the ants' metapleural and mandibular glands have antibiotic and antifungal activity, and are probably responsible for greater seed germinability of several plant species (Ohkawara \& Akino, 2005 and references). The germination velocity can also be increased in the seeds cleaned by ants (Camargo et al., 2016).

In the Atlantic Forest, Guarea guidonia (L.) Sleumer (locally known as carrapeta, Meliaceae) is a common tree species which occurs almost all over Brazil, South and Central Americas (Oliveira et al., 2013). This tree has dense foliage and rapid growth, and is considered an early secondary species (Oliveira et al., 2013). Its fruits are dehiscent capsules with seeds covered by a red sarcotesta. Flowers and fruits are available throughout the year (Pastore, 2003). Seeds are recalcitrant, i.e., they are extremely sensitive to water loss (Connor \& Bonner, 1998). In the present study, we assessed the effect of seed cleaning by ants on the germination of Guarea guidonia. We expected sarcotesta removal performed by ants to result in higher germinability and shorter germination time in comparison with other treatments.

\section{MATERIAL AND METHODS}

\subsection{Study site}

This study was developed in a submontane Atlantic Forest site on Marambaia Island, Sepetiba Bay, state of Rio de Janeiro, southeastern Brazil, in March 2015. The island is located in the Tropical Atlantic Morphoclimatic Domain, with average monthly temperatures above $20^{\circ} \mathrm{C}$. March is one of the warmest months in this area, with a maximum temperature around $30{ }^{\circ} \mathrm{C}$. The average annual rainfall in this area surpasses $1,000 \mathrm{~mm}$, being the period between November and March the wettest months (rainfall indexes higher than $100 \mathrm{~mm}$; Mattos, 2005).

\subsection{Pre-germination treatments}

We collected about 500 seeds from fruits spontaneously opened on G. guidonia trees found in the study area. These seeds were mixed randomly and separated into three groups. They were then placed under three trees with high fruitification rates. The trees were at least $50 \mathrm{~m}$ apart, enough distance to ensure independence of ant colonies. The study treatments comprised: control (no sarcotesta removal), manual removal (sarcotesta manually removed), and sarcotesta removal by ants. In the last treatment, ants had access to seeds; in the other treatments, this access was blocked with trays surrounded by grease all around the perimeter period, but it was also internally covered with soil and leaf litter from the area. This procedure aimed to maintain the same soil conditions in all three treatments. The seeds remained exposed for $40 \mathrm{~h}$. After the exposure period in the field, the seeds were collected and placed in paper bags for each treatment. The ants found removing the sarcotesta were collected for identification, fixed in alcohol 70\%, dry-mounted, and deposited in the Coleção Entomológica Angelo Moreira da Costa Lima (CECL) of the Institute of Biological Sciences and Health, Universidade Federal Rural do Rio de Janeiro.

\subsection{Germination tests}

The germination test was prepared in the laboratory approximately $24 \mathrm{~h}$ after the pre-germination treatment. Seeds with visual signs of predator attack were removed, such as seeds much smaller than the average. Seeds with no contact with ants were randomly divided, and half of them had the sarcotesta manually removed. Due to fungus proliferation on seeds not cleaned by ants, disinfection had to be performed in all treatments to reduce losses. Thus, the seeds were immersed in sodium hypochlorite at $1 \%$ for 
2 min and then washed with distilled water. After this procedure, five drops of neutral detergent were diluted in $100 \mathrm{ml}$ of distilled water. The seeds were immersed in this solution for $5 \mathrm{~min}$ and then washed in distilled water again (Brasil, 2013). The disinfection process was used in order to maintain the analysis more conservative, as Castro et al. (1999) observed germination only on seeds of G. guidonia with anti-fungal treatment.

The three treatments - control, manual removal, and removal by ants - had four replications with 25 seeds each, totalizing 100 seeds per treatment in vermiculite substrate. The experiment was conducted in a germination chamber with constant light at $25^{\circ} \mathrm{C}$, as the germination of G. guidonia seeds is increased by high light and constant temperature (Cardoso et al., 1994; Baskin \& Baskin, 2014). Seeds were monitored weekly to determine the percentage of germinated seeds (germinability), dead seeds, abnormal seedlings, and germination time. Observations continued until all seeds germinated or showed signs of decomposition. Dead seeds, normal, and abnormal seedlings were constantly removed from the experiment.

\subsection{Statistical analysis}

Data were analyzed in the R software. Germinability was calculated as the percentage of seeds that germinated and developed into a normal seedling. It was also calculated the percentage of dead seeds and abnormal seedlings. The emergency speed index (ESI) was calculated as the sum of normal plants observed on a given day divided by the number of days elapsed until that day, so $E S I=E_{1} / N_{1}+E_{2} / N_{2}+\ldots E_{n} / N_{n}$, where $E_{n}$ is the number of normal seedlings in the $n$ day of observation and $N_{n}$ is the number of days of the experiment (Borghetti \& Ferreira, 2004). ANOVA was used to test for differences in germinability between treatments, the percentage of dead seeds, the percentage of abnormal seedlings, and ESI. Previously, normality and homoscedasticity tests were made and, after the analyses, Tukey test was applied.

\section{RESULTS}

All ants found removing G. guidonia sarcotesta on the trays belonged to a single species of the genus Solenopsis. The seeds started germinating approximately one month after the pre-germination test. Observations lasted five months, a period when seeds kept germinating and developing into normal and abnormal seedlings.

The sarcotesta removal by ants influenced germination (Figure 1) and germination speed positively, and the percentage of dead seeds, negatively. The average germinability per treatment was $62 \%$ in control treatment, $78 \%$ in sarcotesta manual removal and $90 \%$ in sarcotesta removal by ants. The germinability varied between treatments $(\mathrm{F}=7.79, \mathrm{p}=0.01)$; only the removal by ants differed from the control treatment (Figure 2a). The average percentage of dead seeds per treatment was $22 \%, 9 \%$ and $6 \%$ for control, sarcotesta manual removal and sarcotesta removal by ants, respectively; the control differed from other treatments $(\mathrm{F}=7.84, \mathrm{p}=0.01)($ Figure $2 \mathrm{~b})$. The average percentage of abnormal seedlings per treatment was 15\%, 13\% and $4 \%$ for control, sarcotesta manual removal and sarcotesta removal by ants, respectively, with no significant difference between treatments $(\mathrm{F}=3.59$, $\mathrm{p}=0.07$ ) (Figure 2c). The average ESI per treatment was $0.1766,0.2836$ and 0.3012 for control, sarcotesta manual removal and sarcotesta removal by ants, respectively; the treatments removal by ants and control differed significantly $(\mathrm{F}=5.84, \mathrm{p}=0.02)$ (Figure $2 \mathrm{~d}$ ). The accumulated number of normal seedlings during the germination test for each treatment are presented in Figure 3. The largest number of normal seedlings and the highest development speed occurred in the treatments including sarcotesta removal (manual or by ants).

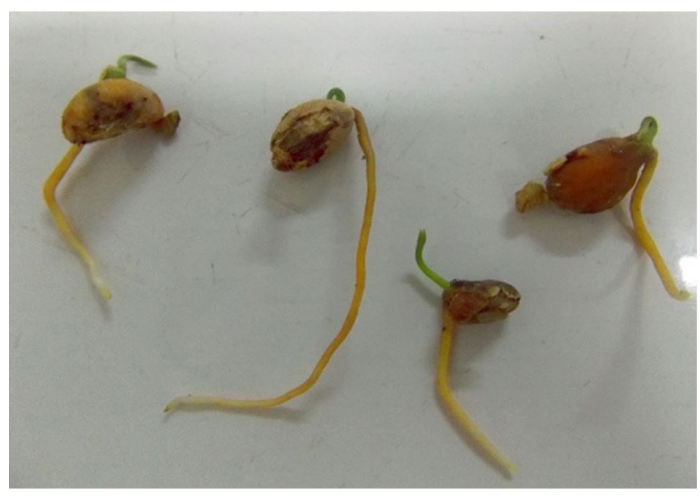

Figure 1. Germinated Guarea guidonia seeds after removal of sarcotesta by ants. 

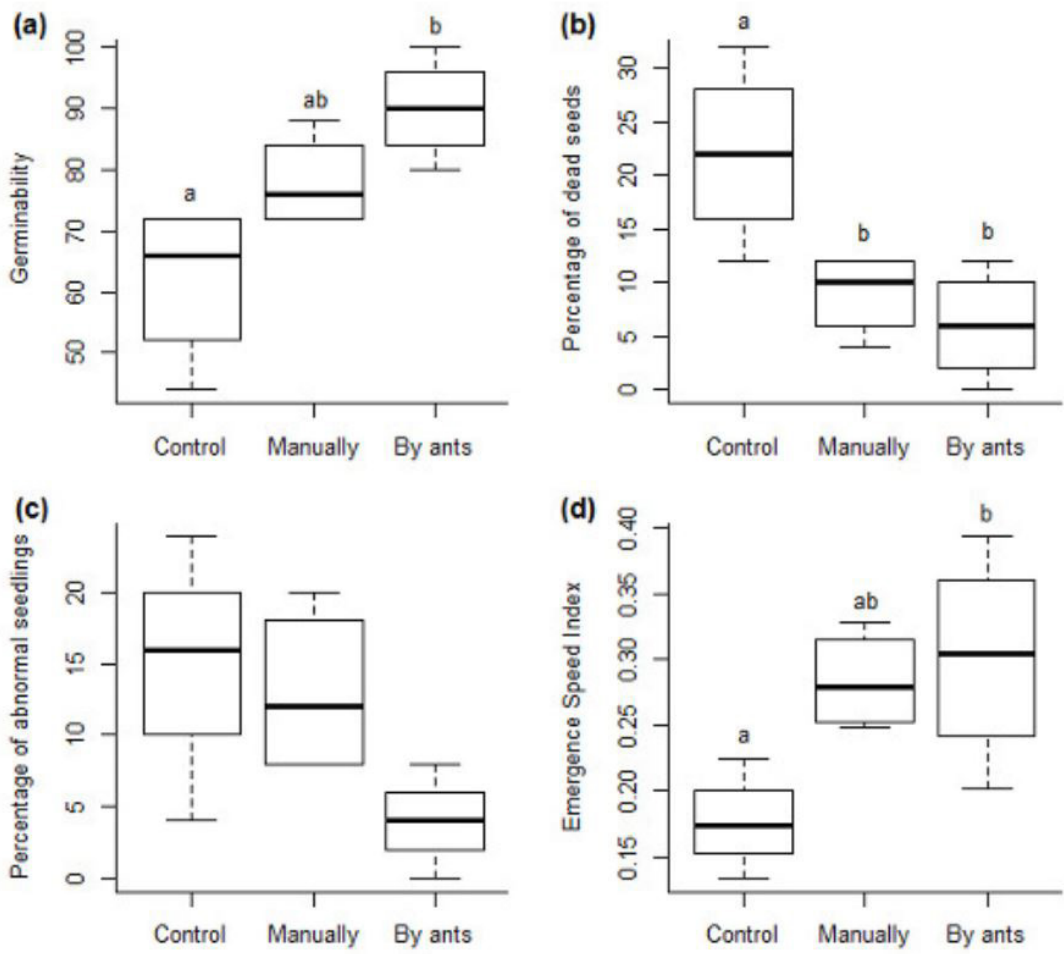

Figure 2. Number of germinated seeds (a), number of dead seeds (b), number of abnormal seedlings (c) and emergence speed index (ESI) (d) for the treatments control, sarcotesta manual removal (manually), and sarcotesta removal by ants in seeds of Guarea guidonia (Meliaceae). Only the number of abnormal seedlings did not differ between treatments.

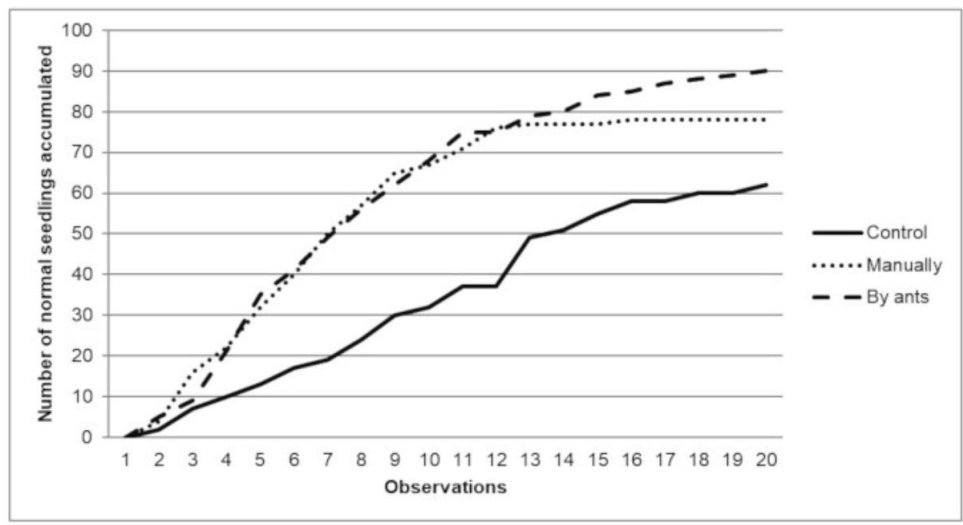

Figure 3. Number of normal seedlings accumulated during 20 weeks of observation for the treatments control, sarcotesta manual removal (manually), and sarcotesta removal by ants in seeds of Guarea guidonia (Meliaceae). The treatments sarcotesta removal (manual and by ants) produced a larger number of normal seedlings, which is faster than that of control.

\section{DISCUSSION}

In the present study, it was showed that the cleaning by worker ants increases germinability and germination speed and decreases the percentage of dead seeds in G. guidonia. This positive effect of removal of the aril or other seed parts by ants had already been observed in previous studies with other plant species (Guimarães \& Cogni, 2002; Passos \& Oliveira, 2003; Passos \& Oliveira, 2004; Christianini et al., 2007; 
Leal et al., 2007). Such studies showed an increase of at least $30 \%$ in germinability compared to the control (Christianini et al., 2007; Leal et al., 2007).

Although these studies showed a positive effect of the removal of appendages from seeds, they discussed only differences in germination between the control (seeds with appendages) and seeds after manual removal of the appendages (Guimarães \& Cogni, 2002; Passos \& Oliveira, 2003; Passos \& Oliveira, 2004; Christianini et al., 2007; Leal et al., 2007). A few other studies analyzed the treatment appendage removal by ants (Oliveira et al., 1995; Ohkawara \& Akino, 2005; Camargo et al., 2016). The comparison in this study is necessary to determine whether an increase in germinability is explained by other factors than the physical removal of appendages (Ohkawara \& Akino, 2005).

The behavior of cleaning seeds and fruits is common in most ant species that interact with fruits (Passos \& Oliveira, 2003; Christianini \& Oliveira, 2013; Santana et al., 2013; Camargo et al., 2016), mainly in the genera Camponotus, Pheidole, Solenopsis and Wasmannia (Christianini et al., 2007). Few species such as poneromorph ants perform seeds removal (Christianini et al., 2007; Leal et al., 2014). Solenopsis species are widely distributed; they are generalist and recruiters, and forage in the leaf litter, trunks, and low vegetation (Baccaro et al., 2015). Several species of this genus have already been recorded cleaning diaspores (Passos \& Oliveira, 2003; Christianini et al., 2007; Santana et al., 2013). The genus Solenopsis dominates in such interactions (Christianini \& Oliveira, 2013), probably due to the mass recruitment of worker ants (Baccaro et al., 2015). Those species are usually considered soil-dominant omnivores associated with anthropically disturbed environments (Baccaro et al., 2015).

Only ant-removed sarcotesta of G. guidonia seeds showed positive germination. Similarly, seeds of Erythroxylum ambiguum Pyr. also had a higher germinability and germination speed in the treatments with passage through the digestive tract of birds or cleaning by ants than in the treatment with manual removal of the pulp (Camargo et al., 2016). This result may indicate the action of antifungal substances secreted by ants (Ohkawara \& Akino, 2005). Another possibility is that the removal of the sarcotesta by ants promotes either chemical or mechanical scarification. Such a process would favor germination by increasing seed coat permeability to water and gases (Traveset \& Verdú, 2002). However, Baskin \& Baskin (2014) demonstrated that G. guidonia produce non-dormant seeds, which makes the scarification possibility unlikely.

The disinfection of the experimental seeds could lead to the rejection of the hypothesis of antifungal action by ants. However, Connor \& Bonner (1998) observed the death of G. guidonia seeds by fungi, even after a $30 \mathrm{~s}$-wash in a $10 \%$ solution of commercial bleach. In addition, Cardoso et al. (1994) state that the low germination of G. guidonia observed in their experiments is probably due to fungi contamination despite prior disinfection treatment. Therefore, it is possible that sodium hypochlorite was not sufficient to prevent fungal growth. The possible antifungal substances secreted by ants might have an action on seeds more effective than the hypoclorite sodium used in this work.

Results from this study show that manual removal of sarcotesta from G. guidonia seeds does not favor germination. Nevertheless, the number of dead seeds was lower than on the non-removal treatment, which suggests the importance of removing the sarcotesta of G. guidonia seeds in forest nurseries cultivating. Some studies conducted on other species showed improved germination on manually removed appendages compared to those not removed (Guimarães \& Cogni, 2002; Passos \& Oliveira, 2003; Christianini et al., 2007; Leal et al., 2007; Lima et al., 2013; Souza et al., 2015). These differences may have resulted from disinhibition effect induced by the aril or pulp removal, which is frequently higher than seed scarification and occurs in several species (Robertson et al., 2006). The lack of physiological studies about the relationship between pulp or aril removal and seed germination prevents further statements.

Despite the results from our study, it is important to consider the natural conditions under which germination experiments occur, as emphasized by Traveset \& Verdú (2002). Robertson et al. (2006) reported that laboratory conditions affect the germinability of intact fruits: in three species with fleshy fruits, the germinability on Petri dishes was zero under laboratory conditions, but it was high under field conditions in New Zealand. Considering the variation between laboratory and field conditions, future studies should be conducted in the field to get a better understanding of germinability and seedling development holistically. 


\section{CONCLUSIONS}

The behavior of cleaning seeds observed in ants promotes higher germinability and emergence speed. Thus, ants act as germination facilitators, helping plants even without dispersing their seeds. As germination is an essential stage of recruitment, ant activity may be important at early successional stages in a degraded area. This importance is even more evident considering that ants are even present since early succession, differently from birds and bats, which are considered the main disperser agents (Lindell et al., 2012). Therefore, studies involving ant behavior can be vital to understand forest restoration. However, we emphasize that the seeds are not dispersed by ants and might suffer high mortality close to the mother plant (Janzen, 1970; Connell, 1971). Thus, these results must be carefully analyzed. Future field studies might better elucidate the results of seed cleaning by ants under natural conditions.

\section{ACKNOWLEDGEMENTS}

We thank the Marambaia Island Assessment Center (CADIM) for the logistical support provided during the present study and for granting us the sampling permit. We also thank Roberto de Xerez, who signed the agreement with CADIM on behalf of UFRRJ so that the present study could be carried out.

\section{SUBMISSION STATUS}

Received: 28 mar., 2018

Accepted: 30 jun., 2018

\section{CORRESPONDENCE TO}

\section{Bianca Ferreira Silva}

Departamento de Ciências Ambientais, Instituto de Florestas, Universidade Federal Rural do Rio de Janeiro - UFRRJ, BR-465, Km 7, CEP 23890-000, Seropedica, RJ, Brasil e-mail: bianca.fsilva@hotmail.com

\section{REFERENCES}

Baccaro FB, Feitosa RM, Fernández F, Fernandes IO, Izzo TJ, Souza JLP et al. Guia para os gêneros de formigas do Brasil. 1st ed. Manaus: INPA; 2015.
Baskin CC, Baskin JM. Seeds: ecology, biogeography, and evolution of dormancy and germination. 2 nd ed. San Diego: Academic; Elsevier; 2014.

Bieber AGD, Silva PSD, Oliveira OS. Attractiveness of fallen fleshy fruits to ants depends on previous handling by frugivores. Ecoscience 2013; 20(1): 85-89. http://dx.doi. org/10.2980/20-1-3573.

Borghetti F, Ferreira AG. Interpretação de resultados de germinação. In: Ferreira AG, Borghetti F, editores. Germinação: do básico ao aplicado. Porto Alegre: Artmed; 2004.

Brasil. Instruções para análise de sementes de espécies florestais. Brasília: Ministério da Agricultura, Pecuária e Abastecimento; 2013.

Brudvig LA, Mabry CM, Mottl LM. Dispersal, not understory light competition, limits restoration of Iowa woodland understory herbs. Restoration Ecology 2011; 19(101): 2431. http://dx.doi.org/10.1111/j.1526-100X.2010.00675.x.

Camargo PHSA, Martins MM, Feitosa RM, Christianini AV. Bird and ant synergy increases the seed dispersal effectiveness of an ornithochoric shrub. Oecologia 2016; 181(2): 507-518. http://dx.doi.org/10.1007/s00442-0163571-z. PMid:26899481.

Cardoso MA, Cunha R, Pereira TS. Germinação de sementes de Virola surinamensis (Rol.) Warb (Myristicaceae) e Guarea guidonia (L.) Sleumer (Meliaceae). Revista Brasileira de Sementes 1994; 16(1): 1-5. http://dx.doi. org/10.17801/0101-3122/rbs.v16n1p1-5.

Castro EM, Alvarenga AA, Almeida LP, Gavilanes ML, Pereira PA. Influência do ácido giberélico e do nitrato de potássio na germinação de Guarea guidonia (L.) Sleum. Revista Árvore 1999; 23(2): 251-254.

Christianini AV, Mayhé-Nunes AJ, Oliveira PS. Exploitation of Fallen Diaspores by Ants: Are there Ant-Plant Partner Choices? Biotropica 2012; 44(3): 360-367. http://dx.doi. org/10.1111/j.1744-7429.2011.00822.x.

Christianini AV, Mayhé-Nunes AJ, Oliveira PS. The role of ants in the removal of non-myrmecochorous diaspores and seed germination in a neotropical savanna. Journal of Tropical Ecology 2007; 23(3): 343-351. http://dx.doi. org/10.1017/S0266467407004087.

Christianini AV, Oliveira PS. Birds and ants provide complementary seed dispersal in a Neotropical savanna. Journal of Ecology 2010; 98(3): 573-582. http://dx.doi. org/10.1111/j.1365-2745.2010.01653.x.

Christianini AV, Oliveira PS. Edge effects decrease antderived benefits to seedlings in a neotropical savanna. Arthropod-Plant Interactions 2013; 7(2): 191-199. http:// dx.doi.org/10.1007/s11829-012-9229-9.

Cole RJ, Holl KD, Zahawi RA. Seed rain under tree islands planted to restore degraded lands in a tropical agricultural landscape. Ecological applications: a Publication of the 
Ecological Society of America 2010; 20(5): 1255-1269. PMid:20666248.

Connell JH. On the role of natural enemies in preventing competitive exclusion in some marine animals and in rain forest trees. In: Den Boer PJ, Gradwell GR, editors. Dynamics of populations. Wageningen: Center for Agricultural Publication and Documentation; 1971.

Connor KF, Bonner FT. Physiology and biochemistry of recalcitrant Guarea guidonia (L.) Sleumer seeds. Seed Technology 1998; 20(1): 31-42.

Escobar-Ramírez S, Duque S, Henao N, Hurtado-Giraldo A, Armbrecht I. Removal of Nonmyrmecochorous Seeds by Ants: Role of Ants in Cattle Grasslands. Psyche 2012; 2012: 1-8. http://dx.doi.org/10.1155/2012/951029.

Gallegos SC, Hensen I, Schleuning M. Secondary dispersal by ants promotes forest regeneration after deforestation. Journal of Ecology 2014; 102(3): 659-666. http://dx.doi. org/10.1111/1365-2745.12226.

Guimarães PR Jr, Cogni R. Seed cleaning of Cupania vernalis (Sapindaceae) by ants: edge effect in a highland forest in south-east Brazil. Journal of Tropical Ecology 2002; 18(2): 303-307. http://dx.doi.org/10.1017/S0266467402002213.

Henao-Gallego N, Escobar-Ramírez S, Calle Z, MontoyaLerma J, Armbrecht I. An artificial aril designed to induce seed hauling by ants for ecological rehabilitation purposes. Restoration Ecology 2012; 20(5): 555-560. http://dx.doi. org/10.1111/j.1526-100X.2011.00852.x.

Janzen DH. Herbivores and the number of tree species in tropical forests. American Naturalist 1970; 104(940): 501-528. http://dx.doi.org/10.1086/282687.

Leal IR, Wirth R, Tabarelli M. Seed dispersal by ants in the semi-arid caatinga of North-east Brazil. Annals of Botany 2007; 99(5): 885-894. http://dx.doi.org/10.1093/ aob/mcm017. PMid:17430980.

Leal LC, Lima MC No, Oliveira AF, Andersen AN, Leal IR. Myrmecochores can target high-quality disperser ants: variation in elaiosome traits and ant preferences for myrmecochorous Euphorbiaceae in Brazilian Caatinga. Oecologia 2014; 174(2): 493-500. http://dx.doi.org/10.1007/ s00442-013-2789-2. PMid:24085639.

Lima HC, Oliveira EG, Silveira FAO. Interactions between Ants and Nonmyrmecochorous Fruits in Miconia (Melastomataceae) in a Neotropical Savanna. Biotropica 2013; 45(2): 217-223. http://dx.doi.org/10.1111/j.17447429.2012.00910.x.

Lindell CA, Reid JL, Cole RJ. Planting design effects on avian seed dispersers in a Tropical Forest restoration experiment. Restoration Ecology 2012; 21(4): 515-522. http://dx.doi.org/10.1111/j.1526-100X.2012.00905.x.

Mattos CLV. Caracterização climática da Restinga da Marambaia. In: Menezes LFT, Peixoto AL, Araújo DSD, Editors. História Natural da Marambaia. Seropédica: EDUR; 2005.
Morellato LPC, Leitão-Filho HF. Padrões de frutificação e dispersão na Serra do Japi. In: Morellato LPC, Editor. História natural da Serra do Japi: ecologia e preservação de uma área florestal no Sudeste do Brasil. Campinas: Editora da Unicamp/Fapesp; 1992.

Ohkawara K, Akino T. Seed cleaning behavior by tropical ants and its anti-fungal effect. Journal of Ethology 2005; 23(2): 93-98. http://dx.doi.org/10.1007/s10164-004-0132-4.

Oliveira PS, Galetti M, Pedroni F, Morellato LPC. Seed cleaning by Mycocepurus goeldii ants (Attini) facilitates germination in Hymenaea courbaril (Caesalpiniaceae). Biotropica 1995; 27(4): 518-522. http://dx.doi.org/10.2307/2388966.

Oliveira RR, Solórzano A, Sales GPS, Beauclair M, ScheelYbert R. Ecologia histórica de populações da carrapeta (Guarea guidonia (L.) Sleumer) em florestas de encosta do Rio de Janeiro. Pesquisas Botânica 2013; 64: 323-339.

Passos L, Oliveira PS. Interaction between ants and fruits of Guapira opposita (Nyctaginaceae) in a Brazilian sandy plain rainforest: ant effects on seeds and seedlings. Oecologia 2004; 139(3): 376-382. http://dx.doi.org/10.1007/ s00442-004-1531-5. PMid:15034779.

Passos L, Oliveira PS. Interactions between ants, fruits and seeds in a restinga forest in south-eastern Brazil. Journal of Tropical Ecology 2003; 19(3): 261-270. http:// dx.doi.org/10.1017/S0266467403003298.

Pastore JA. Meliaceae. In: Wanderley MGL, Shepherd JG, Giulietti AM, Melhem TS, editores. Flora Fanerogâmica do Estado de São Paulo. São Paulo: RiMa; 2003.

Robertson AW, Trass A, Ladley JJ, Kelly D. Assessing the benefits of frugivory for seed germination: the importance of the deinhibition effect. Functional Ecology 2006; 20(1): 58-66. http://dx.doi.org/10.1111/j.1365-2435.2005.01057.x.

Santana FD, Cazetta E, Delabie JHC. Interactions between ants and non myrmecochorous diaspores in a tropical wet forest in southern Bahia, Brazil. Journal of Tropical Ecology 2013; 29(1): 71-80. http://dx.doi.org/10.1017/ S0266467412000715.

Schupp EW, Jordano P, Gómez JM. Seed dispersal effectiveness revisited: a conceptual review. The New Phytologist 2010; 188(2): 333-353. http://dx.doi.org/10.1111/j.14698137.2010.03402.x. PMid:20673283.

Souza ML, Silva DRP, Fantecelle LB, Lemos JP Fo. Key factors affecting seed germination of Copaifera langsdorffi, a Neotropical tree. Acta Botanica Brasílica 2015; 29(4): 473-477. http://dx.doi.org/10.1590/0102-33062015abb0084.

Traveset A, Verdú M. A meta-analysis of the effect of gut treatment on seed germination. In: Levey DJ, Silva WR, Galetti M, editores. Seed dispersal and frugivory: ecology, evolution and conservation. São Paulo: CAB International; 2002. http://dx.doi.org/10.1079/9780851995250.0339. 